\title{
The Esperanto movement in the Dutch East Indies and Indonesia
}

\author{
HEIDI GOES
}

\begin{abstract}
The Esperanto movement in Indonesia has grown in the past five years from being almost non-existent to having a national association with several clubs. One might therefore assume that the Esperanto movement in Indonesia is a totally recent phenomenon. However, already at the beginning of the twentieth century there were Esperantists in the territory of today's Indonesia. Between the two World Wars the movement was active: periodicals and books were published, courses held, and clubs and associations established. As a result of the Second World War this vigorous movement collapsed, but following independence the movement reflourished under the guidance of the Minangkabau journalist and feminist Rangkajo Chailan Sjamsoe Datoe Toemenggoeng. In November 1962 Datoe Toemenggoeng unfortunately passed away, and soon afterward the Esperanto movement again collapsed. Research reveals that this repeated disappearance of the movement was due not only to the death of this leader, but mostly to political factors.
\end{abstract}

KEYWORDS

Esperanto movement, Esperantists, history, Minangkabau, Indonesia.

\section{INTRODUCTION}

Esperanto is a neutral international language created by Ludwig Lejzer Zamenhof (15 December 1859, Białystok - 14 April 1917, Warsaw). The city of Białystok was at that time part of the Russian Empire and is presently in Poland. Under the pseudonym Doktoro Esperanto he launched the first book about the language on 26 July 1887 in Warsaw. It was written in Russian, and soon after appeared also in German, Polish, French, English, and Hebrew. It is commonly called the Unua Libro (First Book). It was not the first nor the last such planned language project of that time or later, but it is the only one until now that has gathered a relatively large community of speakers and

HEIDI GOES obtained a master's degree in African Languages and Cultures in 1999 with a thesis on the history of the Esperanto movement in Africa. In 2007 she started to do research on the Esperanto movement in Indonesia, which led to its revival. She is currently undertaking a $\mathrm{PhD}$ at Ghent University on "A diachronic and spatial analytical approach to linguistic microvariation in the Kikongo language cluster" as part of the KongoKing project. Heidi Goes can be contacted at: heidi.goes@ugent.be.

(c) 2015 Faculty of Humanities, University of Indonesia 
activists around the world. Though the language was launched in Europe, word about it soon spread to other continents as well, often via Europeans travelling abroad.

This article gives an overview of the evolution of the spread of Esperanto in Indonesia, as a language and a movement, both before and after independence. We proceed from early newspaper articles about Esperanto over the first followers to dealing with its ever more active community, which had to be restarted after the Second World War and almost totally disappeared again in the mid-sixties. We have also added short biographies of some important persons in the Dutch East Indian and Indonesian Esperanto movements. At the end we give a short overview of the reactivation during the past decades, and especially during the last five years.

\section{FIRST PERIOD}

\subsection{FIRST MENTIONS OF ESPERANTO IN DUTCH EAST INDIAN PRESS}

Following 1884 dozens of mentions and longer articles appeared yearly in the Dutch East Indies about Volapük, a language published in 1880 in Germany by Johann Martin Schleyer. The fact that another artificial language appeared only three years later probably did not help Esperanto receive positive reviews.

The first two mentions of Esperanto found in the Dutch East Indian press appeared in miscellaneous articles in Soerabaijasch Handelsblad, and these were not at all positive. The first appeared on 13 October 1887, just two and a half months after the publication of Zamenhof's Unua Libro. Only four sentences long, it states that "somebody called dr. Esperanto or so has again thought out a world language". The author, whose name is not mentioned, hopes that the language will not be practically applied, because if new world languages will appear constantly the linguistic situation will get even worse, and "except for the living languages we'll have to learn half a dozen world languages as well" (Soerabaijasch Handelsblad 1887: 2). The second article is somewhat longer and explains la promeso (the promise): Zamenhof had asked the readers of his first book to promise that they would learn Esperanto if ten million other people would subscribe the same promise. The author thinks it is not totally unthinkable that one day this number will be reached, although Zamenhof will not be able to force people to learn his "gibberish". He'll have to content himself with selling ten million copies of his dictionary and grammar; this way he can "easily play at being magnanimous, as he did when writing in his brochure that he renounces every right to the use of the language". The author states that it is only normal that one doesn't have to pay for use of a language, but he actually misinterpreted the statement. Zamenhof didn't mean that he wasn't charging for the use of the language, but that he was permitting people to use it freely, as they wished.

The author ends this review of the first Esperanto book by stating that he'll leave dr. Esperanto alone to fight it out with pastor Schleyer over the tens and tens of millions (Soerabaijasch Handelsblad 1888: 1). Much more positive mention of Esperanto was found a few years later in the newspaper Het Nieuws van den 
dag; Kleine Courant of 8 July 1894, which reported on a letter about Esperanto from Leo Tolstoy (1828-1910) that had appeared in the Russian newspaper Nedelja on 12 June of the same year. This article, with full translation of the letter into Dutch, was reproduced in De Locomotief; Samarangsch Handelsen Advertentieblad on 15 August 1894. In the following months and years articles appeared occasionally in the Dutch East Indian press, sometimes positive, sometimes negative, sometimes theoretical, sometimes reporting on big Esperanto happenings or small anecdotes or about the growth of the movement in the Netherlands, sometimes making Esperanto the object of a joke or a comparison with for example other languages (but not only with languages).

One of the more remarkable and definitely most interesting comparisons that were made was the one between Malay and Esperanto. In De Sumatra Post (1909) we can read that Malay, as non-Malay speak it, has become a "kind of Esperanto [...] for all the peoples who meet in these countries". In 1910 the same newspaper uses the expression Oostersch Esperanto (Eastern Esperanto) to refer to Malay, without even explicitly using the word Malay anymore. A few years later De Sumatra Post uses the comparison in a report about Russian musicians in Surabaya with whom the secretary of the music hall, who wanted to pay them, could not communicate, not even using "the Esperanto of India" (De Sumatra Post 1917).

Besides Esperanto and Volapük, other planned languages were mentioned in the Dutch East Indian press at the end of the nineteenth and beginning of the twentieth century such as Idiom Neutral (1902), Solresol (1817), La Langue Bleue (1896), etcetera but it goes beyond the scope of this article to treat all of these here.

\subsection{THE FIRST ESPERANTISTS IN THE DUTCH EAST INDIES}

At the beginning of the twentieth century there were already Esperanto pioneers in the Dutch East Indies. Most of these were foreigners, predominantly Dutch and British, who went there to work as company employees, officers, teachers, and sailors (Esperanto 1927b). Among these first Esperantists were L. Keidel in Kandang-Jati, Probolinggo in 1902 and G. van der Noordaa in Surabaya in 1903, both in East Java (L'espérantiste 1902, 1903). We do not know much about these individuals other than that both were adepts of the Société pour la propagation de l'Espéranto (SPPE, Society for the Propagation of Esperanto) ${ }^{1}$ and appeared as such in the French periodical L'espérantiste. Keidel was originally a mechanic at the sugar factory of Kandang-Jati, but from 1907 on worked as an agent for the Sangerhäuser Actien-Maschinenfabrik und Eisengießerei (Sangerhäuser Machine Factory and Iron Foundry) (L'espérantiste 1902; Tutmonda Jarlibro Esperantista 1906, 1907). The Jubilea Jarlibro 1937 (Jubilee Yearbook 1937) of the Universal Esperanto Association (henceforth UEA) mentions on the same island also A.C.A. Boers, who had appeared in the

From 1903 on: Société Française pour la Propagation de l'Espéranto (SFPE, French Society for the Propagation of Esperanto). 
Yearbook since 1905. The first Esperantist found in Sumatra was Th. Razout Kühr in Bajung Lintjir, in 1906.

In addition to the already-mentioned names, the Tutmonda Jarlibro Esperantista, enhavanta the adresaron de Dro Zamenhof por $1906^{2}$ published also the names of (Van) Lakerveld and W. Marinissen. Boers and Van der Noordaa did not reappear in the following year's edition, in which the following names were nonetheless added: Gerritsen Plaggert in Batavia (now Jakarta), Mrs. J.S.R. Baerveldt-Haver and Miss F. van Loon in Padang (West Sumatra), and J. Magnée in Medan (North Sumatra). All of these were members of the Holanda Societo Esperantista "La Estonto estas Nia" (L.E.E.N., the Dutch Esperanto Society "The Future is Ours") from the Netherlands.

The first UEA delegate ${ }^{3}$ in the Dutch East Indies, Rupert Falkland Vaughan, was a British citizen who learned Esperanto in the British Indies in 1905. From 1909 until 1916 he was an UEA delegate in Totok, Celebes (now Sulawesi), and until 1912 the only UEA delegate in the country, joined in 1913 by Albert Knegt. Vaughan later went to live in Sandakan, British North Borneo (now Malaysia) (Jarlibro IEL-UEA 1947). Knegt was a post-office employee in Surabaya and later officer at the coffee plantation of Banyuwangi, East Java. He participated in the Esperanto World Congresses in 1911 and 1920, and served as a UEA delegate without interruption until 1925 (see series of Jarlibro 1909-1925).

In this period there were few Esperantists and they were scattered over the country. According to Vaughan in a letter to the periodical Hinda Esperantisto (1932; see also Sections 2 and 7.1 about this periodical), these were thinking about an association, a Malay "key" ${ }^{4}$ and so forth, but owing to the small number of Esperantists that kind of action was not possible. The allegation in The British Esperantist in August 1912 that one was constantly hearing about the language's being studied by both Europeans and natives thus seems to us to be too positive.

\section{AWAKENING AND EARLY ASSOCIATION IN THE $1920 \mathrm{~S}$}

Probably the first Esperantists in the Dutch East Indies who were also born there were Liem Tjong Hie in Semarang, who learned Esperanto in 1919 and remained active for seventy years (see his biography in Section 7.1) and Kho Yok Siang, both of Chinese descent. Kho Yok Siang learned Esperanto as an autodidact in 1920 using a book his brother brought with him from Japan, where the latter had studied (Doi 1995: 59-60). In the following years the interest in the language grew. Some began to teach Esperanto and to write and publish in the language. The number of UEA delegates went up almost every year, from two in 1920 to nineteen in 1934 (see series of Jarlibro 19201934). Later the number fell again.

2 Worldwide Esperantist Yearbook, containing the addresses of dr. Zamenhof for 1906.

3 Names and addresses of delegates are mentioned in the Yearbook of UEA. Delegates are prepared to help other members of UEA with information and practical help.

4 Esperanto ŝlosiloj, or "keys", are small booklets with the sixteen basic rules of Esperanto grammar and a basic word list. Often they are the first introductory texts about Esperanto for speakers of a given language. 
In 1922 the Nederlandsch Indische Esperantisten-Vereeniging (Dutch East Indian Esperantist Union) was founded. Its members were mostly of Dutch descent but there were also locals, almost all residents of Java. During its short existence, in the years 1922 and 1923, Albert Knegt published its periodical Esperanto - Propagandablad der Nederlandsch Indische Esperantisten-Vereeniging (Esperanto - Propaganda Leaflet of Dutch East Indian Esperantist Union) in Banyuwangi.

From August 1922 till April 1923 a course appeared in the periodical Neratja, under the direction of the judge P.W. van den Broek, who used Esperantist as his pseudonym. Its lessons appeared approximately every two or three weeks. The only person who made the exam after the lessons was the Javanese Kamso Wirdjosaksono (Neratja 5/5/1923 and Holanda Esperantisto 1924). After the departure of P.W. van den Broek, the machinist J.T. Kaptein, an army corporal, began teaching Esperanto to Kamso Wirdjosaksono (Holanda Esperantisto 1924).

The protestant pastor Richeld Willem Frans Kyftenbelt (5 November 1865, Surabaya - 11 January 1952, Utrecht $)^{5}$ founded the Esperanto women's club at the beginning of 1923 in Menado, Celebes. The members were locals (Minahasa), Europeans, and Chinese ${ }^{6}$. There were three courses, divided according to the age of the women, with a total of eighty students (Esperanto Triumfonta 1923a). Unfortunately, at the end of the year the pastor left the country and returned to the Netherlands (Esperanto Triumfonta 1923b). There are mentions of several publications in 1924. Kamso Wirdjosaksono, Klaten, would have started publishing the propaganda periodical India Esperantisto in Malay, including Esperanto lessons but we have not found the physical periodical anywhere (Esperanto Triumfonta 1924). P.W. van den Broeck was about to publish the Malay grammar of Esperanto but no proofs have been found of its actually having been published, only anticipatory announcements ${ }^{7}$ (Esperanto Triumfonta 1924). Liem Tjong Hie did certainly publish the first prose booklet about Java in Esperanto: Javaj legendoj kaj fabloj (Javanese legends and fables).

In May 1925 there was an appeal of J. Brotomidjojo in Heroldo de Esperanto (1925a) to the more or less thirty Esperantists in the country, especially to the UEA delegates Raden Mardio in Yogyakarta, Soetjipto in Sumenep, Rassat in Padang, and others, to encourage them to act vigorously for the spread of Esperanto. Brotomidjojo himself began a course with ten persons in June of the same year, and Wirdjosaksono another course with fifteen persons, both in Klaten (Heroldo de Esperanto 1925c). At the end of the year the teacher George

5 For these dates, places, and his full name: see Utrechts Nieuwsblad (1952a, 1952b). Also available from: http://records.ancestry.com/richeld_willem_kyftenbelt_records. ashx?pid=66631011, http:/ / www.royalblood.co.uk/D1114/I1114829.html.

6 It is not clear if the author meant Indonesians from Chinese descent or (recent) Chinese immigrants, or both.

A list of periodicals and books mentioned in at least one source but not found physically can be found in https://sites.google.com/site/esperantoenindonezio/historiosejarah/serchata. 
Leopold Blot began a free course in Jetis, Yogyakarta. More than thirty young Catholics participated and at the end a branch of Internacia Katolika Unuigho Esperantista (IKUE, International Catholic Esperantists Union) was established with nine members. This expanded to eleven in 1925, but diminished to only one in 1935. The hope of G.L. Blot for an East Indian Union of Catholic Esperantists had apparently been too ambitious (Espero Katolika 1925).

From 1925 on the Dutch East Indian Esperantists began to write for international Esperanto magazines. Wirdjosaksono wrote about Javanese marriage customs (Wirdjosaksono 1925) and Liem Tjong Hie about the Malay language, both for Esperanto (Liem 1928). Heroldo de Esperanto (1925b) published a translation from the hand of Liem Tjong Hie of an article about the uneasy feelings among the various ethnic groups in Java.

In the first issue of Hinda Esperantisto - Organo de la tuthinda Esperantistaro (Indian Esperantist - Organ of the all-India Esperantists) in October 1925, the editor Liem Tjong Hie called for reunification and mutual support of the "Esperantists in India", regardless of race, religion or language (Hinda Esperantisto 1925). The magazine was willing to be the organ of the new union and project a general picture of the global development of the Esperanto movement. At the same time Liem wanted to use his magazine to promote the language. Because of this there were articles in English, Dutch, Javanese, and Malay. Although Liem clearly was sceptical about the state of the movement ("which actually cannot be called a movement"), he was very enthusiastic and laborious. The first issues contained articles on various topics, from the history of the Dutch East Indies to literature and the Esperanto movement in other countries, apparently all written or translated by himself.

\section{1926- 1941: FROM GROWTH TO SUDDEN COLLAPSE}

From 1926 on and until the beginning of the Second World War the movement in the Dutch East Indies, although not big, was very lively among both the Dutch and the natives. Several periodicals, (text) books and articles appeared, courses were held on several islands, clubs and associations were established, and the Esperantists campaigned in various ways with success. This vigorous movement was to collapse because of the Second World War.

In 1926 prof. dr. J. van Rees gave several lectures on Esperanto, in Bandung and Surabaya (De Indische Courant 1926a, 1926b, 1926c). On 18 January 1927 there was a lecture by R.W.F. Kyftenbelt in the Christian Marist House in Surabaya. People who were interested could join the new course starting 27 January (De Indische Courant 1927a). Also in the local Hogere Burgerschool (HBS, Higher Civic School) Kyftenbelt was teaching and, according to De Indische Courant, the students were making fast progress (De Indische Courant 1927b). The two courses together had 35 students (Esperanto 1927a). However, only a few months later he was moved to Pontianak (West Kalimantan), where he began a course with fifteen members. The lessons in Surabaya were taken over by H. Jansen and J.A. Sens, respectively (De Indische Courant 1927c). In the same city there were also fourteen persons who followed an Esperanto 
course by means of correspondence with the Nijmegen Esperanto club in the Netherlands (De Indische Courant 1928). After the course in Pontianak Kyftenbelt taught Esperanto also to students on other islands, for example in Belitung (Esperanto 1928). The following quotation (my translation) from the December 1927 issue of Esperanto shows that students in the former Dutch East Indies were not only from Dutch descent: "[...] there are already indigenous supporters, and it should be noted that their Esperanto style is uniform - like that of Europeans - except for their imaginative expressions that realistic and non-poetic westerners are not capable of" (Esperanto 1927b). At the end of 1928, during a congress of the Nederlandsch-Indisch Onderwijzers Genootschap (Dutch-Indian Teachers Society) in Surabaya, IJsselstein, a Dutch professor and Esperantist residing in the city, argued for Esperanto. The result was that two proposals on the desirability of the teaching of Esperanto to teachers and in schools were accepted. In the same article from Holanda Esperantisto one speaks of "about seventy samideanoj in India" (Holanda Esperantisto 1929).

In 1929 Unuiĝo de Geesperantistoj en Nederlanda Hindujo (Vereeniging van Esperantisten in Indië - Union of Esperantists in Dutch East India) was founded by Liem Tjong Hie. Together with the July-August 1929 issue of Hinda Esperantisto a newsletter and registration form was sent and the founding of the union mentioned in the November-December 1929 issue (Hinda Esperantisto 1929). At the end of 1929 the union had only eleven members (Hinda Esperantisto 1930a). Despite the free membership and his enthusiasm and hard work the number of members in the union in 1930 was, according to Liem, deplorable (Liem 1930). However, he did not mention any numbers anymore. Knowing that by mid-May 1931 there were only eight subscribers to Heroldo de Esperanto (a then very popular international Esperanto magazine) in the Dutch East Indies, the low number should not have been too surprising. However, he continued the publication of Hinda Esperantisto at least until 1934. ${ }^{9}$

In 1931 Dirk Mijndert Pot created the Orienta Esperanto-klubo (Eastern Esperanto-club) with only "indigenous people not knowing modern languages" in Balikpapan (East Kalimantan). It had fifteen members (Heroldo de Esperanto 1931). The Orienthinduja Centra Esperanto-Organizo (OCEO, East Indian Esperanto Organization), founded in 1933, was more successful. It was a "neutral federation of groups, which are independent and to which neutrality is not obligatory". The secretary was F.W. Buenting, in Batavia. The countrywide organization was composed of Europeans, indigenous Indonesians and Chinese in Borneo, Sumatra, Java, and Celebes. Buenting published a magazine and correspondence courses in Malay and Dutch. The Malay course was led by K. Wirdjosaksono in Klaten (La Praktiko 1933a, 1933b). In August 1933 the OCEO membership had already reached 358. Its radio course in Batavia, arranged with the help of the Batavian Radio Union and led by G.H. de Heer, was a success. The grammar booklet Korte grammatica 
van het Esperanto was published, and in 1934 Interligilo, the monthly organ of the organization, briefly appeared (Heroldo de Esperanto 1933; Interligilo 1934a, 1934b). Most of its first issue was occupied by a vocabulary list aimed at helping readers understand the sample issue of the magazine Heroldo de Esperanto sent together with the new periodical. The second issue, only half as extensive as the first, contained little other than reprinted material from other Esperanto magazines. We do not know of later issues.

The independent monthly organ La Sperto (The Experience), founded in 1935 in Makassar, Celebes, had a more varied and original content. Its editors were A.R. Mewengkang and P. Mamesah. The articles were written in Malay, English, and Esperanto. It contained among other things an Esperanto course, articles about politics and industry in Indonesia and about Esperanto in Makassar, and original poetry (La Sperto 1935a, 1935b). But it too was short-lived. The following year, however, the Selebesa Esperanto-Asocio ${ }^{10}$ (Esperanto Association of Sulawesi) was founded in Makassar, thanks to the initiative of Servius Mamesah. Its treasurer Tarachand was "a British Indian who very actively collaborated with the Indonesians for the dissemination and propaganda of Esperanto among his countrymen in Makassar". All other board members were Indonesians: president Abdul Malik, secretary Sahibu, and board members E.M. Anang and Rafiuddin (Heroldo de Esperanto 1936; Esperanto Internacia 1936). In June 1936 an official Esperanto examination, probably the first in the Dutch East Indies, was held. The examination commission examined twelve students at the A-level, ten of which passed. The only student participating at B-level passed as well. Examinations were organized several times after this (La Praktiko 1936). In November 1936 the first issue of Nia Organo (Our Organ), the organ of the new Dutch East Indian Esperantist Society La Estonteco Estu Nia (Let the Future Be Ours) was published. The association was aimed especially at Dutch speakers in the Dutch East Indies, and its organ had to serve as this link and at the same time develop its members' knowledge of Esperanto and inform them about the state of the Esperanto world. K. Gorter edited the magazine (Nia Organo 1936). The association campaigned several times successfully in the mass media: an Esperanto course appeared for example in the newspaper De Malanger (Nia Organo 1937), Schoutens did a radio course in Malang (Nia Organo 1938a), and ten articles about Esperanto (written by J.F.L. Lumaye Schuld) appeared in the journal Soerabaja-Post (Nia Organo 1938b). In 1938 there was also an exhibition of Esperanto books in Surabaya. This promotion resulted in several courses and new branches of the society, for example the Esperanto clubs of Cheribon and Bandung.

In 1940 there were UEA delegates in Bandung, Batavia, Cheribon, Yogyakarta, Garut, and Sebelawan (Jarlibro 1940; Nia Organo 1940b); courses were held in Bandjarmasin, Bandung, Blitar and Cheribon (Heroldo de Esperanto 1940). In March 1940 the local club in Bandung organized a

10 The name was wrongly spelled, probably influenced by the pronunciation. It should have been Celebesa instead of Selebesa. 
successful celebration with an exhibition (Nia Organo 1940a). In the SeptemberOctober issue of Nia Organo the Society's decision to contact the Internacia Esperanto-Ligo (IEL, International Esperanto League) in order to become its affiliated association was published (Nia Organo 1940b). By the end of 1940 the Esperantists managed, after several attempts, to publish the Dutch textbook Ons Eigen Leerboek (Our Own Learning Book), edited by K. Gorter, the editor of Nia Organo (Nia Organo 1940c). On 14 January 1941 C.M. Hamaker delivered a successful speech in Garut advocating Esperanto. A large number of participants joined the course that he guided afterwards (Nia Organo 1941a). In November 1941 it was announced that the first Annual General Meeting in Bandung, would be held on 26 and 27 December 1941 (Nia Organo 1941b). No reports of this meeting have been found, so it is not certain that it actually happened. We have not found any later issues of Nia Organo after the November 1941 one. Only a few weeks later the Second World War became a reality also for Indonesia, and most probably La Estonteco Estu Nia stopped functioning. The movement collapsed, and several Esperantists perished in the battle against the Japanese or were taken captive in the Japanese concentration camps (Heroldo de Esperanto 1947).

\section{ATTEMPTS TO REVIVE THE MOVEMENT}

In October 1948 the general secretary of the national Dutch Esperanto Society La Estonto Estas Nia in the periodical Nederlanda Esperantisto (Dutch Esperantist) called for the names and addresses of other Esperantists (military and civilians) to initiate contacts among isolated Esperantists in Indonesia. But the call does not seem to have had any result in restarting an Esperanto movement in Indonesia.

In 1949 Servius Mamesah published the monthly periodical Indonesia Perspektivo in Makassar, but we can be sure only about a single August issue. It had four pages and almost all articles were both in Indonesian and Esperanto. No news about any Esperanto activities in Indonesia was mentioned. Most of the space was used for politics in Indonesia, and the transcript (and translation) of the speech of Zamenhof during the first Esperanto World Congress, in 1905 in Boulogne-sur-mer, France.

In 1950 the Esperanto-worker's magazines Laborista Esperantisto and Sennaciulo mentioned the founding of Indonezia Esperantista Asocio (Indonesian Esperantist Association) in Jakarta, which "has as a goal to bring together all Esperantists in Indonesia for more effective progress". Only an address, but no name was mentioned, maybe on purpose because the initiator was Dutch. Willy Wagenaar was mentioned as president of the association in a 1950 directory of Hugo Steiner, director of the International Esperanto-Museum in Vienna, Austria at the time (Steiner 1950: 150). However, until now, we've found no indication about if and how long the association was active and what the association would have done.

We can see that relatively soon after the World War, even during the battle for independence, there were attempts to relaunch the movement, by both Dutchmen and Indonesians - however without much success. 


\section{1952- 1965: PERIOD OF SUCCESS \\ 5.1 Datoe TOEMENGgOENG RESTARTS THE MOVEMENT}

Rankajo Chailan Sjamsoe Datoe Toemenggoeng, ${ }^{11}$ a politician, female-rights activist and journalist, started to learn Esperanto most probably in 1950 in Indonesia (Het Nieuwsblad voor Sumatra 1952). ${ }^{12}$ She participated in the Esperanto World Congress in Munich in August 1951 and after that spent three months in the Netherlands, amongst other activities lecturing in Esperanto about Indonesia and about the matriarchal system of her own ethnic group, the Minangkabau, in Sumatra (La Praktiko 1952a). She arrived back in Indonesia on 6 December 1951 (Isbrücker 1951; Arwani [1954]) and she started working in order to "build an Esperanto-movement in Indonesia". At the beginning of 1952 she sent letters to newspapers and got answers from longtime Esperantists who helped her (Esperanto 1952a; La Praktiko 1952a; Datoe Toemenggoeng 1951, 1953). One of the groups founded was the one in Medan (North Sumatra) led by Hasan Basri and Liong Soen Kiat (La Praktiko 1952b).

In 1952 Datoe Toemenggoeng founded the Indonezia Universala Esperanto-Asocio (Indonesian Universal Esperanto-Association), later called Indonezia Esperanto-Asocio (IEA, Indonesian Esperanto Association) (Esperanto 1952b). Most of the movement during the following decade in Indonesia was initiated as a result of her work; but Liem Tjong Hie was also still working and publishing, as he would also in later decades. Concrete activities consisted of establishment of courses and clubs in the bigger cities on various islands, and of editing periodicals, textbooks and dictionaries. The movement culminated in the first national conference, in April 1960 in Jakarta (Voĉ el Indonezio 1960a).

After the establishment of IEA, Datoe Toemenggoeng organized several courses in various cities. The students set up several clubs, which functioned as sections of IEA. In 1959 there were ten sections apart from the centre in Jakarta: in Bandung, Yogyakarta, Magelang, Semarang, Surabaya, Malang, Lubuk Linggau, Den Pasar, Makassar, and Waingapu, so six in Java and one a piece in Sumatra, Bali, Sulawesi, and Sumba (Voĉo el Indonezio 1959). At the end of courses Datoe organized examinations followed by a party, during which she handed out the diplomas and students gave lectures. This again aroused interest and recruited new students (for example Voĉ el Indonezio 1954b). Sometimes these students participated in an exhibition or in the Commercial Fair for Women, which Datoe Toemenggoeng organized (Voĉ el Indonezio

11 See Section 7.2 for her biography and for a longer version, in Indonesian: http:// jakarta.kompasiana.com/sosial-budaya/2012/11/22/mengenang-kembali-chailansjamsoe-1905-1962-510094.html.

12 It is not clear how she started to learn Esperanto. In an interview with Het Nieuwsblad voor Sumatra (1957) Datoe Toemenggoeng states having learnt Esperanto in 1950 for only two months, and that she was invited to the World Congress in August 1951 in München because of her correspondence with a (non-specified, but probably the Universal Esperanto) Association of Esperantists in London. However, from La Praktiko (1951) we learn that she studied Esperanto during three months to be able to attend the said congress. She arrived back in Indonesia 6 December 1951 (Isbrücker 1951; Arwani [1954]). 
1954a). This was another avenue for finding many more new students. In 1954 the College for Teachers in Bandung started an Esperanto-course led by Miss De Jager. This was mentioned as the first state school in which Esperanto was taught. Other courses were held in several non-state schools (La Praktiko 1954).

Several Indonesians have become board members in international organizations that Datoe Toemenggoeng founded and presided, namely Sudazia Esperanto-Federacio (South-Asian Esperanto Federation) (Sudazia Bulteno 1958) and Islama Esperanto-Asocio (Islamic Esperanto Association) (Voĉ el Indonezio 1960b, 1960f). This is not astonishing if one takes into account that the movement in Indonesia was regarded as the most organized in the region. In the first issue (15 December 1958) of Sudazia Bulteno, the organ of the South-Asian Esperanto Federation, Tibor Sekelj, ${ }^{13}$ one of the initiators of the Federation, wrote about the movement in South-Asia: "The Esperantists of this region, who have always been few and unorganized (except in Indonesia), felt isolated from each other and from the rest of the movement. Any link has long been needed" (Sudazia Bulteno 1958).

\subsection{PERIODICALS, TEXTBOOKS, AND DICTIONARIES}

In January 1953 the first issue of the periodical La Modera Voco de Indonezia UEA (The Moderate Voice of Indonesian UEA) was published. At least four issues appeared: three in 1953 and one in 1954, edited and almost entirely written by Datoe Toemenggoeng. Probably right after these four issues the periodical was renamed Voĉ el Indonezio ${ }^{14}$ (Voice from Indonesia). It appeared irregularly till at least April 1960. Datoe Toemenggoeng was the chief editor, but from 1960 on A. Rachman was added as editor. In June 1958 Liem Tjong Hie relaunched his own quarterly magazine (see Section 7.1) as well, but with a different name, Indonezia Esperantisto. It appeared for at least two years. However, Liem also wrote for Voĉ el Indonezio, which demonstrates at least some contact between the two activists.

In the 1950s several readers, textbooks, and dictionaries written by various Indonesian Esperantists were published. In 1952, for example, Pramudja published the textbook Buku peladjaran Esperanto and Hasan Basri published Peladjaran bahasa pantja-benua (writing exercises for it later in 1970). In 1956 the textbook Esperanto sebagai bahasa internasional jang praktis dan efektif by Lim Ek Thoean was published. In 1958 M.J. Soekirdjo Dirdjosoebroto published a small dictionary and textbook (Marilah kita beladjar bahasa Esperanto). Small courses appeared in the children's magazines Kawanku in Yogyakarta (for example, Broto 1958) and in Meladipri, an addition to the newspaper Sin Min from Medan

13 Tibor Sekelj (14 February 1912, Spišská Sobota - 20 September 1988, Subotica) was a well-known Esperanto author, traveler and explorer (http://en.wikipedia.org/wiki/ Tibor_Sekelj).

14 The magazine was wrongly spelled Voĉ el Indonesio at first. The first issue of 1958 had the name Voĉ el Indonesia, still incorrect. From the second issue of 1958 its name was correctly spelled Voĉ el Indonezio. For ease of reference we use only this last title in the text and also for the head entry in the references at the end of the article. Under this head entry, the specifically used titles can be found. 
(Sumatra) (for example, Marsoehar 1958). In 1960 the Medan Esperanto group of Medan published a dictionary of more than 200 pages compiled by Hasran Basri and Liong Soen Kiat (Kamus bahasa Esperanto - Esperanto-Indonezia vortaro).

Liem Tjong Hie, who was very active even before the war, continued also after it. His publishing company following independence was called Indonezia Esperanto-Instituto (Indonesian Esperanto Institute). Liem wrote or translated several self-published books for students of Esperanto: in 1960 an introductory textbook with a dictionary (Selajang pandang bahasa Esperanto dengan kamus Esperanto - Indonesia dan daftar kata dagang), and probably the same year a booklet about the structure, evolution, and progress of Esperanto (Bahasa Esperanto - Azas'2, Perkembangan dan Kemadjuannja); and in 1961 a translation of the Esperanto Fundamento, ${ }^{15}$ including its dictionary. Arwani published readers for beginners in 1954 (Ĉirkaŭ la domoj kaj kortoj en Indonezio, with a second edition in 1958) and in 1957 (Mia Esperanta dialoglibro).

\subsection{CULMINATION: FIRST CONFERENCE OFTHEINDONESIAN ESPERANTO ASSOCIATION}

The Indonesian Esperanto Association wanted to organize a congress in 1959 to celebrate the 100th anniversary of Zamenhof's birth. However, due to some difficulties, not the least because Datoe Toemenggoeng stayed in Europe for a longer time than anticipated following the Esperanto World Congress in Warsaw, and because the organizers did not receive permission for a large congress, the event was delayed until April 1960 and became a conference instead of a congress (Voĉ el Indonezio 1960a). From 1 to 3 April 1960 "sympathizers, representatives of our groups, and individual longtime Esperantists from different regions of our Fatherland" (my translation from Esperanto) met in Jakarta (Voĉ el Indonezio 1960c). The program began with an exhibition of books, periodicals, brochures, and Esperanto correspondence. There were speeches by the governor of Jakarta, the ambassador of Poland, and a representative of the Ministry of Education, Teaching, and Culture. Following this a small team of Esperantists staged the drama La EsperantoDomo (The Esperanto House), which described the cohabitation of different peoples of the world living in a friendly and peaceful manner with only one language, Esperanto (Voĉ el Indonezio 1960d: 2). During various sessions in the conference several organizational matters regarding the periodical, the statute and the membership card were decided upon. The affiliation of IEA to UEA was postponed. The second conference in Yogyakarta was also planned (Voĉo el Indonezio 1960e). Datoe Toemenggoeng reported that it was the first time that they officially presented the Esperanto movement to the Indonesian people, and especially to the Indonesian government. According to her, the members of the government showed a great interest and sympathy to the Esperanto movement in Indonesia during the conference. A few days later newspapers

15 The Fundamento, published in 1905 by Zamenhof, is the basis of the Esperanto language, binding all Esperantists. It consists of a Foreword (Antaŭparolo), a Grammar (Gramatiko), a collection of exercises (Ekzercaro) and a Universal Dictionary (Universala Vortaro). 
published long articles about Esperanto. Parts of these articles later appeared with translation in Voĉo el Indonezio (1960d).

\section{COLLAPSE OF THE MOVEMENT IN THE $1960 \mathrm{~S}$}

For some time during my research, I tied the rapid decline of the movement in Indonesia that followed to the death of Datoe Toemenggoeng, because it took place during the same period. But from conversations with vetarano ${ }^{16}$ it became evident that something quite different caused the almost total disappearance of the movement in the sixties. It was the anti-communist aftermath of the Gerakan 30 September [1965] (Thirtieth of September Movement) causing many killings and arrests of either communists or people supposed to be communists. Being just a bit different or having a dispute with someone could be enough to be persecuted or murdered. In such an atmosphere the Esperantists no longer dared to gather. Were they communists? Perhaps some of them were, most probably not, but they had plenty of reasons to fear being regarded as communists. First of all, many of the Esperantists were Indonesians of Chinese descent (partly or completely), one of the targets of the paramilitary involved in the killings. Additionally, the Indonesian Esperantists in that period had many contacts with the Esperanto movement in communist countries, such as China and several countries in Eastern Europe. They used to correspond and receive Esperanto magazines from those countries, while Indonesia forbade Chinese magazines and meetings of Indonesians of Chinese descent. Indonesian Esperantists feared that the government would suspect them to be sections of the Partai Komunis Indonesia (PKI, Indonesian Communist Party). So they feared to meet, or even to own Esperanto books and magazines, which therefore quickly caused the disappearance of the movement $\left(\mathrm{Heroa}^{17}\right)$. Chinese were also not allowed to hold gatherings. Later, Indonesians with Chinese names had to change their name into an Indonesian name. At least part of them used Esperanto as an inspiration, not only for themselves but also for their children, what shows how important the language was for them. So, for example, there are Esperantists in Indonesia named Heroa Wibisono (who named his daughters Eta Esperantina, Mila Esperantina and Tria Estiana, the first of which was one of my first students) and Esperantista Gunawan Wibisana (with children Esperantistina Venus, Esperantista Yudhistira and Esperantista Isa), both of which participated in the congress in April 2013 (Rijanto, Heroa, Gunawan ${ }^{18}$ ). Eriko Sunardo (who has now passed away, see Section 9.2) also took an Esperanto name.

16 People who speak Esperanto for several decades are called veteranoj (veterans).

17 According to a letter from Heroa Wibisono, 5 December 2009 to the author.

18 Rijanto Husadha in an interview with the author, 20 December 2012, at his home in Bogor. For Heroa see footnote 17. Names of Gunawans children were noted during an interview with the author in November 2009. 
7. BIOGRAPHIES OF IMPORTANT FIGURES IN THE INDONESIAN ESPERANTO MOVEMENT

\subsection{LiEM TJONG Hie (15 JanuARY 1906, SEMARANG-? APRIL 1991, SEMARANG)}

Liem Tjong Hie studied in the regional Dutch schools. It may have been there that he became acquainted with Esperanto, because already in 1919, when only 13 years old, he learned the language (Kökény L. kaj Bleier V. 1933-34: 339). In 1924, the same year that he published Javaj legendoj kaj fabloj (see Section 2) he became a delegate of UEA, which he was regularly to remain until 1989 (Jarlibro 1924-1989). In 1925 he started editing the periodical Hinda Esperantisto, which would appear irregularly until 1934. He also founded Ekstremorienta Esperanto-oficejo kaj -Instituto or Centraal Esperanto-Bureau \& -Instituut, an office for publications and courses (according to several advertisements in Hinda Esperantisto, for example in Hinda Esperantisto 1930b, 1930c, 1930d).

In 1927 Liem translated and published the famous story Historio de Saidjah kaj Adinda of Multatuli (1820-1887). He also wrote and/or published several instructional books both in Malay and in Dutch, for example the Malay key (translated in 1928 but not printed until 1933, owing to technical problems of its publisher, the Belgian Esperanto Association); Esperanto en zijn verbreiding with a foreword by J.A. Sens, about the spread of Esperanto in the world (1931); the textbook Leerboek der wereldhulptaal Esperanto (1932); and the informational work Apa itoe Esperanto? (1933). He also translated the Fundamento into Indonesian. Under the pseudonym Rimba Djohar he wrote also in Indonesian, for example about confucianism and the state philosophy Pancasila (Djohar 1969). Under the pseudonym Hie Kiguj he wrote the children's book La varma sudo kaj la frosta nordo in 1966, published in China. He still appeared in a 1981 directory of Esperantists as a university lecturer (Anonymous 1981: 133). According to information received by his colleagues (Ridwan, ${ }^{19}$ personal communication, 2010 and 2012), he taught English commercial correspondence and general correspondence in the college Akademi Bahasa 17 Agustus 1945 (in short: Akaba 17) in Semarang.

\subsection{Rankajo Chailan Sjamsoe Datoe Toemenggoeng (6 April 1905, BUKITTINGGI-23 NOVEMBER 1962, JAKARTA?) 20}

Rankajo Chailan Sjamsoe received an education in Dutch schools, which meant that she was more educated than the average Indonesian woman during this period (Blackburn 2000: 186). She married Landjoemin gelar Datoe Toemenggoeng, a state employee for the Persvoorlichtingsdienst (State Communication Service). They lived and worked in Batavia, where her husband was from 1935 to 1939 a member of the People's Council for the Perhimpunan Pegawai Bestuur Bumiputra (PPBB; Association for the

19 E-mails of Evy Ridwan, colleague of Liem Tjong Hie with the author, 28 February 2010 and 7 October 2012.

20 See El Popola Ĉinio (1962); http:/ / www.fembio.org/english/biography.php/woman/ notable-women. 
Indigenous State Officials) (Blackburn 2000: 189, 2004b: 99).

Already very young, Datoe Toemenggoeng became an advocate of women's rights and was active in various women's-rights organizations. For at least four years she was president of the association Perkumpulan Pemberantasan Perdagangan Perempuan dan Anak-Anak (P4A; Association for the Elimination of Commerce of Women and Children) following its founding in 1931 (Datoe Toemenggoeng 1936a: 55; Blackburn 2004a: 174; Wieringa 2002: 76). During the same period she was active also for women's right to vote. At the latest in 1931 Datoe Toemenggoeng joined the Batavia section of Vereeniging voor Vrouwenkiesrecht in Nederlands-Indië (VVV; Association for Women's Suffrage in Dutch East India). She was one of the two Indonesian members (the other being R.A. Roekmini Santoso), who were also briefly members of the association's board (Blackburn 2004a: 91, 2004b: 85).

In June 1938 she attended the first Congress of the Indonesian Language in Solo. This congress was to commemorate the Youth Pledge (Sumpah Pemuda) of 1928, in which three ideals had been declared: one country, one nation and one language. In December 1938 she founded with Entjik Noerdjanah the women's section of Persatoean Minangkabau (Union of Minangkabau) in Betawi, which she chaired (Pedoman Isteri 1938).

After the war Datoe Toemenggoeng continued to be active. She wrote several books about and for women, largely practical household works but not exclusively. She wrote, for example, a 1958 book about thirty years of action against polygamy (30 tahun menentang polygami.). She was also known for organizing the Commercial Fair for Women a number of times in Jakarta. From 1951 on she took part in several Esperanto World Congresses. Datoe Toemenggoeng encouraged and strengthened the Esperanto movement in Indonesia since the end of 1951 or beginning of 1952 (see footnote 12), when she returned from Europe after her first Esperanto World Congress. She was president of the Indonesian Esperanto Association, South East Asian Esperanto Federation, and Islamic Esperanto Association (see Section 5.1). Because of her encouragement, and through help from Indonesians who had learned Esperanto previously, more and more sections of the Indonesian Esperanto Association were founded. Datoe Toemenggoeng initiated and supported the publication of several textbooks and dictionaries written by other Indonesian Esperantists. She wrote the book Dengan paspor Republik Indonesia (With a passport of the Republic Indonesia, [1959]) about her travels, in which she also discusses Esperanto. Probably her last visit to Europe was during the Esperanto World Congress in Brussels in 1960. She died two years later, only 57 years old. She had nine children (Het Nieuwsblad voor Sumatra 1957) and at least eleven grandchildren. None of these we've been able to locate at the time of this article's publication, despite some intensive searching.

\section{FOREIGN ESPERANTISTS IN INDONESIA}

Several Esperantists from other countries visited Indonesia, especially in the thirties. They each tried in their own way to promote Esperanto during 
their visit, for example by giving radio or newspaper interviews. They also often published accounts of their encounters with Indonesian Esperantists in Esperanto books or periodicals, and in newspapers in their home country. This was important in a time when very little was known about the movement in countries far away from Europe. Because of this and because these experiences of these Esperantists also give an insight into the Esperanto movement in Indonesia or into the way Indonesian Esperantists experience Esperanto we mention some of these varied visitors.

\subsection{JOSEPH ROMAN SCHERER (24 JANUARY 1901, KERZERS-2O JULY 1967, ?LOS ANGELES)}

The active Esperantist Joseph R. Scherer, a Swiss-American bank officer and journalist, undertook a world tour for and using Esperanto from 17 September 1930 to 21 February 1932. He did it on his own initiative, partly because he longed to travel and experience adventures but also to represent the Internacia Centra Komitato de la Esperanto-Movado (International Central Committee of the Esperanto Movement) in Geneva, Switzerland, which helped organize the trip (Scherer 1933: 266). Scherer spent almost four weeks in Indonesia, more precisely in Java and Bali. He visited Mrs. J. Roorda, an Esperantist in Buitenzorg (current Bogor) (Scherer 1931a, 1931b), and met Liem Tjong Hie twice in Semarang before and after his visit to Bali. In Semarang he gave radio speeches and had long discussions about world language problems with Liem Tjong Hie (Soerabaijasch handelsblad 1930; Scherer 1931c, 1931d). In Heroldo de Esperanto Scherer praised Liem and informed the readers that the latter wanted to create an Esperanto Centre in Semarang with 'slower methods' (Scherer 1931c). In another article he explains that the climate in the tropics is not suitable for white people, and that recruitment for Esperanto should be in the hands of persons born in the tropics. He therefore hoped that Liem could gather all the forces on the island and called on everyone already in Java or planning to go there to collaborate with Liem, "[...] who was born there, is very good at speaking our language and will always be in the country" Scherer (1931d: 2). This call appears to have been in vain, because very little cooperation between Liem and the Dutch Esperantists in Java has been noted.

\subsection{NiCK H. SLINGER (CIRCA 1904, NETHERLANDS-?)}

This Dutch Esperantist and journalist decided to accompany his teacher and colleague J.R. Scherer during his world journey. But when Scherer left Indonesia, Slinger stayed a few months longer (Scherer 1933: 128; Slinger 1931: 1). At the end of his stay in Surabaya he had spoken twice in Dutch about Esperanto in local radio broadcasts of Soerabaiasche Radio Vereeniging. On 20 April 1931 Slinger spoke about how he learned Esperanto and about the pleasure it gave him during a trip to Japan and China. The following week, on 27 April 1931, he made another speech about Esperanto on the same radio station. It is possible to follow his journey around the country through his radio speeches: on 5 May he spoke on the radio in Batavia (Bataviaasche Radio 
Vereeniging), and on 13 and 29 May on the Christian radio station in Medan, Sumatra. ${ }^{21}$ People who were interested in Esperanto could contact Mr. W. Iken. De Sumatra Post mentioned personal details about Slinger, the places he had visited, and that he "even in Dolok Ilir found an Esperantist". Unfortunately the paper does not mention the name of this latter Esperanto speaker.

\subsection{MiYATAKe Seidô (6 September 1912, NARA-16 August 1944, ?NARA; REAL NAME: MIYATAKE MASAMICHI)}

Miyatake Seidô visited Java in August 1932. He made this visit as an official representative of the city Nara (Japan) and its ethnographical museum. His purpose was to make a study of the museums, especially with respect to ethnographies, and to promote Esperanto. He was also interested in the local languages (Het Nieuws van den Dag voor Nederlandsch-Indië 1932; Bataviaasch Nieuwsblad 1932). On 6 August he visited the city Semarang and met Liem Tjong Hie at his shop. Miyatake told Liem that he came to Java to study the Javanese language and folklore, and Liem gave him his work Javaj legendoj kaj fabloj and some other books. The next day Miyatake visited Batavia and met amongst others the Dutch Esperantists Willem Iken and G.H. de Heer (Miyatake 1932a). The same evening an article appeared in Bataviaasch Nieuwsblad that explained the purpose of Miyatake's journey and described his language knowledge and immediate travel plans. Esperanto is mentioned only as one of his goals (Bataviaasch Nieuwsblad 1932).

\subsection{EugĖne Gaspard Marin (6 OCTOBER 1883, BosvoORde-27 SEPTEMBER 1969, GLOUCESTERSHIRE)}

A totally different traveller was the anarchist and pacifist Gaspard Marin, the son of a British mother and a Belgian father. In 1928 he decided to travel for three years in the Old World, but eventually travelled for ten years throughout the world, using Esperanto especially in the second half of the trip. He wrote many notes along the way, but published very little (Marin 1974: 5-14). We can, however, find some interesting notes in his typescripts. ${ }^{22}$ In 1934 he passed through Semarang and met Liem Tjong Hie. After the meeting Liem wrote in his travel book (cited from Marin typescripts, my translation): "In the same way my friend and fellow-thinker rejoices in our meeting, I feel very happy to be able to be with him, even if for a short time. Our Esperanto is really a wonderful language. It is not just a language: it is linked with something else, something higher, something one can only feel. That mystery links men like

${ }^{21}$ Surabaya: De Indische Courant (1931a: 2, 1931b: 9), Soerabaijasch Handelsblad (1931: 6); Jakarta: Het Nieuws van den Dag voor Nederlandsch-Indië (1931a: 11, 1931b: 10), Bataviaasch Nieuwsblad (1931a: 1, 1931b: 6); Medan: De Sumatra Post (1931a: 5, 1931b: 5, 1931c: 2, 1931d: 2).

22 All papers in Esperanto of Marin were kept by Michael Grendon, son of Hilda Gustin, the lady who had nursed Marin during his last years. He gave it in October 2012 to Hilary Chapman, a British Esperantist (Chapman 2013: 37). He had sent a scanned version of the typescript to Gotoo Hitosi, through whom I got to know about this typescript and who sent them to me with permission of Chapman. The ten pages were typed in 1984 and were used for lectures and articles (for example, Marin 1951: 7-8). 
brothers". Marin seems to have passed a long time in the country, because in the end he could not stay in Semarang even one more day after meeting Liem because of visa problems. He had to take the train immediately to Batavia and leave the country. He still had some difficulties, but the officer in charge spoke Esperanto and helped him. Unfortunately Marin doesn't mention the name of the officer in his typescripts.

\section{INDONESIAN ESPERANTISTS ABROAD}

There were also Esperantists from Indonesia going abroad for different reasons, mostly to Europe, or Indonesians learning Esperanto while they were in Europe. We know about some of them because they were active in some way.

\subsection{Haji Raden Mustapha (11 September 1911, Semarang-? 1939 1940,23 GRAZ)}

Probably the first Indonesian Esperantist to lecture about Indonesia in Europe was Raden Mustapha. He was still very young when he left the country in 1929. He visited sixteen European and six other countries. In 1931 he was in Prague, where he learned Esperanto, and later toured Czechoslovakia from 15 February until 27 March 1934, lecturing 31 times in 29 places for 10000 people. From September 1934 until May 1935 he gave lectures in Sweden, invited by Sveda Esperanto-Federacio (Swedish Esperanto Federation) (Heroldo de Esperanto 1935).

\subsection{ERIKO SUNARDO (15 JULY 1926,24 LAWANG-2 FEBRUARY 2001, 25 VIENNA; BY BIRTH KHO KWAT LIAT)}

One of the Indonesian Esperantists most known by the Esperanto movement outside his country was Eriko Sunardo. He was a six-year-old boy when the Hungarian Esperantist Fedorchak visited his father Kho Yok Siang, who had been an Esperantist since the 1920s (see Section 2). This was his first contact with Esperanto. When he went to college, Eriko Sunardo started to learn the language diligently, and in 1945 he began corresponding with foreigners and contacting Esperanto organizations from other countries. He studied

23 We've found an indication about the date of his death only in a radio-interview with Sunardo (1995).

$24 \quad$ Normally 1927 is cited as birth year (for example, Esperanto 2002). However, according to Josua Sunardo, his son, Eriko changed the year of his birth in his own papers, so as to escape military service during the Second World War (interview of the author with Josua Sunardo, 13-14 February 2013 at his home in Vienna).

25 In Esperanto (2002) the mentioned year of his death is 2002. However, according to Josua Sunardo (see footnote 24) and Heine (e-mails with Tanja Heine, 20-21/2/2013, administrator of graveyard Simmering in Vienna about the exact day of death of Eriko Sunardo) Sunardo died in 2001, not 2002. The mistake in Esperanto (2002) might find its base in the fact that only on 22 March 2002 the urn of Sunardo was put in the grave and because they only know about his death in 2002. 
at the Academy for Foreign Service in Jakarta (Akademi Dinas Luar Negeri). ${ }^{26}$ In 1959 he participated in the fifteenth International Youth Congress of Tutmonda Esperantista Junulara Organizo (TEJO, the Worldwide Esperantist Youth Organization), in Gdansk, and in the 44th Esperanto World Congress in Warsaw. During the latter Congress he gave a lecture about Esperanto and the Indonesian peace movement for the Mondpaca Esperantista Movado (Esperantist Movement for World Peace) (Paco 1959). Later he participated in several Esperanto World Congresses. In the 1960s he lived in the United Kingdom (1962-1964) and in France (1967-1970); in both countries he took part in the Esperanto movement (E. Sunardo 1995).

In 1975 Sunardo began working as first secretary and cultural attaché of the Indonesian Embassy in Vienna, Austria (The Australian Esperantist 1975). Because of his marriage with Mirjana Ilić, a Yugoslavian and thus a nonIndonesian citizen, the embassy terminated his employment. In 1983 their only son, Josua Sunardo, was born. After the death of his wife in 1986 and a subsequent six years in Indonesia, Sunardo returned to Austria with his son. After a difficult period during which he had to do menial work to survive, Eriko Sunardo could again work at the Embassy (interview of the author with Josua Sunardo, 13-14 February 2013). In an interview with Emil Vokal for the Esperanto radio of Vienna, Eriko Sunardo told about the history of the movement in Indonesia, and about the then-recently established Esperanto club (E. Sunardo 1995). This showed that he followed the movement in his native country, but we cannot find traces of his participation in the movement there.

\section{CENSORSHIP}

At several moments in the history of the Dutch East-Indies and Indonesia the Esperanto movement was affected by censorship. The censors seemed to be able to understand Esperanto as sometimes they added information about the contents of the magazines in the Politiek-Politioneele Overzichten ("politicalpolice overviews', reprinted in Poeze 1983, 1994). At least starting in 1929 Esperanto magazines were withheld: these were two left wing magazines, from Russia and Germany respectively (Poeze 1983: 177, 261). From June 1935 till June 1939 almost every month at least one, sometimes several Esperanto magazines, brochures or booklets were withheld, and sometimes sent back with the stamp "interdit". These were mostly left wing (pacifists, labourers, socialist, communists) but there was also one catholic magazine (Bulteno Katolika). Also the other magazines censored were often left wing, but sometimes also extreme right wing, or catholic (Poeze 199427). Some of the senders tried to by-pass the censorship: in February 1939 two copies of the communist monthly magazine Popola Fronto were sent wrapped in Santa Clause paper (Poeze 1994: 271). In the first years after the independence of

26 E. Sunardo (1995).

27 Poeze (1994: 32, 44-45, 88, 123, 152, 153, 169, 185, 202, 220, 233, 234, 251, 271, 285, 298, 299, 307). 
Indonesia, there was virtually no censorship, but in 1957 control was restored with the imposition of martial law (Cribb and Kahin 2004: 70). Esperanto publications sent from the Netherlands were forbidden to enter the country and sent back. La Praktiko, printed in the Netherlands, asked therefore his readers from other countries to send material in and about the language ( $\mathrm{La}$ Praktiko 1958).

\section{REACTIVATION}

Research so far has revealed only a few attempts to reactivate the movement in Indonesia during the first forty years following 1965. As one example, Indonezia Esperanto-Societo (Indonesian Esperanto Society) was reestablished in Semarang in 1990, having first been established 16 July 1976 (Anonymous n.d.: 1). It published among other things at least eleven issues of Voco el Indonezio in $1991 .{ }^{28}$ The club was active only very irregularly, with long periods of non-activity until the end of 2007 when its leader, Francis D. Yury, passed away, and the club activity quickly ended. ${ }^{29}$ At the end of the 1990s the longtime Esperantist Riyanto Husadha occasionally tried to teach new students in Bogor, and after that some individuals in Indonesia began to learn the language, especially via Internet. ${ }^{30}$ Additionally, there were and still are a few veteranoj left in the country. The Esperanto movement outside Indonesia knew only about a few of these veterans and new Esperantists. They hardly began to create a new movement. Both Indonesian Esperantists and the movement outside the country ignored or had forgotten that there previously had been an active movement in Indonesia. This was one of the reasons for the present research of this author, which began in 2007. Two years later I decided to try to do some fieldwork as well, in order to meet personally Esperantists who remembered the active period of the fifties and sixties. However, Lee Jungkee, a Korean board member of the Komisiono pri la Azia Esperanto-Movado (KAEM, Commission for the Asian Esperanto Movement), inspired me to use the occasion of my visit to teach Esperanto as well. I accepted the challenge. The result was that almost every year from 2009 until 2014 (not in 2011, twice in 2012 but only one week in 2014) I have been in Indonesia for several weeks to inform children, students and adults about Esperanto. Already on 3 October 2010 we founded the first Indonesian club of the century, in Jakarta, and in 2013 the first Indonesian Esperanto Congress was held in Bogor (5-8 April). ${ }^{31}$ Currently there are active clubs in Bandung,

28 One issue has been found, no. 11 of November 1991. No year collection number is mentioned, but it was probably the first year, as the movement had restarted in 1991 (Voĉ el Indonezio 1991).

29 Letter of B.J. Haryono to Renato Corsetti (then, 3 December 2007 about the passing away of their teacher, asking what to do now; personal communication with former members of the society (Henry Hartaka Hardjadinata, Imam Prayoga, Atieq Wigoena, and Elizabeth Yuliani) and with Andri Yudi Handoko, Yury's son, and Marjamah, Yury's widow, 13-17 November 2009.

30 Rijanto Husadha, see footnote 18.

31 Short films about the congress are available from https://sites.google.com/site/ 
Jakarta, Medan, and Yogyakarta, and less active clubs or individuals learning Esperanto at least in Aceh, Ambon, Banjarnegara, Batam, Bogor, Denpasar, Makassar, Malang, Padangan, Pekalongan, Semarang, and Surabaya. Learning material in Indonesian has been produced and is now sold by the national association, Indonezia Esperanto-Asocio, founded during the Congress on 7 April 2013. The Facebook group Esperanto en Indonezio/Esperanto di Indonesia and several Facebook pages of separate Indonesian cities are well visited and active, with not only Indonesians but also foreign Esperantists. ${ }^{32}$ The Facebook-group is a very good spot for people who've just heard or read about the language, to find information on how to start to learn and/or to meet others who have just decided to learn or have been studying for a time.

My decision to do fieldwork in Indonesia has led indirectly to the reactivation of the movement there since November 2009. The results of my research have also been valuable material for use during introductory sessions with students or interviews with newspapers, radio, and television, in explaining that Esperanto is actually nothing new in Indonesia and that the Indonesian movement has a remarkable history. I hope that among the many people in Indonesia presently interested in Esperanto I will be able to find people who still remember something or someone from the former movement there. I invite them to contact me to tell their story, so it would not be lost.

\section{REFERENCES}

\section{BASED ON PERIODICALS 33}

\section{Bataviaasch Nieuwsblad}

1931a "Esperanto", Bataviaasch Nieuwsblad (4 May) 46/125: 1.

1931b "Radio-nieuws", Bataviaasch Nieuwsblad (5 May) 46/126: 6.

1932 "Seido Miyatake - Bestudeert inheemsche folklore en talen", Bataviaasch Nieuwsblad (7 August) 47/?: ?34

\section{De Indische Courant}

1926a "Esperanto", De Indische Courant (4 November) 6/43: 5.

1926b "Esperanto", De Indische Courant (16 December) 6/79: 2.

1926c "Esperanto", De Indische Courant (17 December) 6/80: 2.

1927a "Esperanto", De Indische Courant (19 January) 6/106: 2.

1927b “Esperanto", De Indische Courant (20 January) 6/107: 2.

1927c “Esperanto cursussen", De Indische Courant (7 April) 6/170: 2.

esperantoenindonezio/kongreso/filmetoj.

32 An overview of Facebook pages and other contact details are available from https:/ / sites.google.com/site/esperantoenindonezio/indoneziaj-esperantistoj.

33 No authors mentioned, too many to put under anonymous; alphabetically according to title of periodical.

34 The article was copied into the first part of Miyatake (1932b: [5]), with other illustrations, without notation about page or issue number of the original article in Bataviaasch Nieuwsblad. 
1928 "Onderwijs; Esperanto", De Indische Courant (24 August) 7/284: 6.

1931a "Radio-rubriek; Lezingen over Esperanto", De Indische Courant (16 April) 10/176: 2.

1931b "Radio-rubriek; Esperanto voor de radio", De Indische Courant (21 April) 10/180: 9.

De Locomotief; Samarangsch Handels- en Advertentieblad

1894 "Het oordeel van Graaf Tolstoi over eene wereldtaal”, De Locomotief; Samarangsch handels- en advertentieblad (15 August) 43/188: 2.

De Sumatra Post

1909 “De 'lingua franca' voor Indië“, De Sumatra Post (15 June) 11/136: 6.

1910 "Ons Dagelijksch Nieuws; Medan, 5 December; Sint op tournée", De Sumatra Post (5 December) 8/276: 6.

1917 "Mirovitch en Plastro", De Sumatra Post (10 May) 19/109: 5.

1931a "Esperanto; Uitzending van de Nicro", De Sumatra Post (11 May) 33/108: 5 .

1931b "Uitzendingen van de Nicro", De Sumatra Post (11 May) 33/108: 5.

1931c "Sumatra de Nicro-uitzendingen", De Sumatra Post (27 May) 33/120: 2.

1931d "Een wereldreiziger-journalist; Met Esperanto de wereld om", De Sumatra Post (10 June) 33/132: 2.

El Popola Ĉinio

1963 "S-ino Rkj. Ch. Sj Datoe Toemenggoeng Forpasis", El Popola Cinio. [14]/1: 44 .

\section{Esperanto}

1927a "Tra la mondo esperantista. Kroniko; Hindio Nederlanda", Esperanto 23/2: 41 .

1927b "Tra la mondo esperantista; Kroniko; Indio Nederlanda", Esperanto 23/12: 15.

1928 "Kroniko; Borneo (Nederlanda Indio)", Esperanto 24/1: 13.

1952a "Indonezio", Esperanto 48/3: 68-69.

1952b "Indonezio", Esperanto 48/11: 293.

2002 "Forpasoj. Eriko Sunardo", Esperanto. 95/6: 142.

Esperanto Triumfonta (later Heroldo de Esperanto)

1923a "Saluto al Celebes", Esperanto Triumfonta (6 May) [4]/135: [2].

1923b "Kroniko; Azio; Nederlanda Hindujo", Esperanto Triumfonta (2 December) [4]/168: [2].

1924 "Kroniko - Azio - Java insulo (Nederlanda Hindujo)", Esperanto Triumfonta (13 April) [5]/187: [3]. 


\section{Esperanto Internacia}

1936 "Estraro de Selebesa Esperanto-Asocio", Esperanto Internacia 1/2: 7.

Espero Katolika

1925s "Nia Movado en Nederlanda Hindujo", Espero Katolika 1/5: 73.

Heroldo de Esperanto (new name of Esperanto Triumfonta since 1925)

1925a "Kroniko; Azio; Nederlanda Hindujo", Heroldo de Esperanto (16 May) [6]/38: [3].

1925b "Java estanteco ; Malagrabla sentado, kiu floras", Heroldo de Esperanto (5 May) [6]/39: [3].

1925c "Kroniko; Azio; Nederlanda Hindujo", Heroldo de Esperanto (13 June) [6]/45: [4].

1931 "Kroniko de l'Esperanto-movado; Nederlanda Hindujo", Heroldo de Esperanto (27 November) [12]/48: 4.

1933 "Esperanto Vivas; Nederlanda Hindujo", Heroldo de Esperanto (17 September) 14/37: 3.

1935 "Hadzi Raden Mustapha", Heroldo de Esperanto (3 March) 16/9: 3.

1936 "Estraro de Selebesa Esperanto-Asocio", Heroldo de Esperanto (15 October) 16/3: 2.

1940 "Post sesmonata milito: Kiel statas Esperanto tra la mondo?", Heroldo de Esperanto (1 March) 21/5: 1.

1947 "Ankau Azio revekighas por Esperanto", Heroldo de Esperanto (1 March) 23/5: [1].

Het Nieuws van den Dag; Kleine Courant

1894 "Het oordeel van Graaf Tolstoi over eene wereldtaal", Het Nieuws van den Dag; Kleine Courant (8 July) 21/27: 2.

Het Nieuws van den Dag voor Nederlandsch-Indië

1931a "Bataviasche Radio Vereeniging", Het Nieuws van den Dag voor Nederlandsch-Indië (4 May) 36/100: 11.

$1931 b$ "Radio-nieuws", Het Nieuws van den Dag voor Nederlandsch-Indië (5 May) 36/101: 10.

1932 "Japansch geleerde op bezoek", Het Nieuws van den Dag voor Nederlandsch-Indië (10 August) 37/185: 6.

Het Nieuwsblad voor Sumatra

1957 "Mevr. Datoek Toemenggoeng, La batiko kiel pasporto", Het Nieuwsblad voor Sumatra (6 September) 10/2679: 2. 
Hinda Esperantisto ${ }^{35}$

1925 "Al la legantoj", Hinda Esperantisto 1/1/: 1-2.

1929 "Unuigho de gesperantistoj en Nederl. Hindujo", Hinda Esperantisto (November-December) [3]/6: 4.

1930a "Unuigho de Geesperantistoj en Ned. Hindujo", Hinda Esperantisto (January-February) [4V7: 4.

1930b "Ekstremorienta Esperanto-Oficejo kaj -Instituto", Hinda Esperantisto (January-February) [4/7: IV.

1930c "Ekstremorienta Esperanto-Oficejo kaj -Instituto", Hinda Esperantisto (March-April) [4]/8: III.

1930d "Esperanto-Bureau \& Instituut 'Liem Tjong Hie' Semarang", Hinda Esperantisto (July-August) [4]/10: [I].

1932 "Esperanto en antaŭa tempo", Hinda Esperantisto 4[6]/16: 46.

\section{Holanda Esperantisto}

1924 "Esperanto en Hindujo", Holanda Esperantisto 3/38-39: [4].

1929 "Esperanto in Nederlandsch-Indië; Paŝo post paŝo", Holanda Esperantisto 8/77: 65-66.

Interligilo

1934a "Ĉe la Unua Numero", Interligilo (March) 1/1: 1.

1934b Interligilo (April) 1/2: 1.

Jarlibro (Yearbooks, based on chronological order)

Oficiala Jarlibro

1908-10 Oficiala Jarlibro de Universala Esperanto-Asocio. Paris/Génève: Universala Esperanto-Asocio.

1911-16 Oficiala Jarlibro. Génève: Universala Esperanto-Asocio.

1919 Oficiala Adresaro. Bern: Universala Esperanto-Asocio.

1920 Oficiala Jarlibro. Bern: Universala Esperanto-Asocio.

1921-23 Oficiala Jarlibro. Génève: Universala Esperanto-Asocio.

1924-36 Oficiala Jarlibro de la Esperanto-Movado. Génève: Universala Jubilea Jarlibro Esperanto-Asocio.

1937 Jubilea Jarlibro de la Esperanto-Movado. Génève: Universala Esperanto-Asocio.

35 The numbering is rather chaotic. Hinda Esperantisto appeared in 1925, and then from 1928 till (at least) 1933. 1929 still had "first year" as notation; this changed by the end of the year to "first volume". 1930 had: "second volume"; 1931: "third era", 1932: "fourth era", and by the end of the year: "fourth year"; 1933: "fifth year". The number of the issues are continuous. Because it was neither the fifth year since 1925 neither the fifth year of publication, we mention between square brackets the number of the publication year. So 1930 is the fourth year that the periodical appeared (not counting 1926 and 1927, when no issue appeared). Numbering mentioned on the issue is also noted if any. 
Jarlibro de la Internacia Esperanto-Ligo

1937-46 Jarlibro de la Internacia Esperanto-Ligo. Heronsgate: Internacia Esperanto-Ligo.

Jarlibro IEL-UEA

1947 Jarlibro IEL-UEA. Heronsgate: Internacia Esperanto-Ligo.

Jarlibro de la Universala Esperanto-Asocio

1948-55 Jarlibro de la Universala Esperanto-Asocio. Heronsgate: Universala Esperanto-Asocio.

1956-89 Jarlibro [each with the year added to the title]. Rotterdam: Universala Esperanto-Asocio.

Laborista Esperantisto

1950 "El la mondo esperantista", Laborista Esperantisto 19/8: 61.

La Praktiko

1933a "Al la venko! - 107. Esperanto-organizo en Orienta Hindujo", La Praktiko. 2/6: 4.

1933b "Informoj; Nederlanda Hindujo", La Praktiko. 2/6: 11.

1936 "Informoj; Nederlanda Hindujo", La Praktiko 5/9: 13.

1951 "Oriento kaj Okcidento interamikiĝas per Esperanto", La Praktiko 15/7-9: 89.

1952a “S-ino Rankajo ...", La Praktiko 16/4-5: 47.

1952b "Esperanto ekfloris en Indonezio", La Praktiko 16/10: 132.

1954 "Informoj; Indonezio", La Praktiko 18/6: 92.

1958 “Informoj.; Indonezio", La Praktiko 22/9: 126.

La Sperto

1935a La Sperto 1/1: [1]-4.

1935b La Sperto 1/2: [1]-4.

L'espérantiste

1902 "Nouvelles adhésions (novaj aliĝoj); Membres adeptes", L'espérantiste 5/56-57: 95.

1903 "Société française pour la Propagation de l’Esperanto; Nouveaux candidats (novaj kandidatoj); Adeptes", L'espérantiste 6/71: 308.

Nederlanda Esperantisto

1948 "Esperantistoj en Indonezio", Nederlanda Esperantisto 13/10: 101. Neratja

1923 "Oedjian Esperanto", Neratja (5 May) 7/88: 4.

Nia Organo

1936 "Esperanto Radio-Kurso", Nia Organo 1/1: 5. 
1937 "Korte berichten - Esperanto-cursus in Indisch Dagblad", Nia Organo 2/2: 113.

1938a "Mededelingen", Nia Organo 2/3: 125.

1938b "Mededelingen", Nia Organo 2/10: 202.

1940a "De Bandoengse Feestavond", Nia Organo 4/5-6: 36-37.

1940b "Mededelingen", Nia Organo 4/11-12: 78-79.

1940c "Mededelingen", Nia Organo 5/1-2: 90.

1941a "Mededelingen", Nia Organo 5/3: 100.

$1941 b$ “(Sen titolo)", Nia Organo 6/1: 1, 12.

Paco (Danish-Swedish issue)

1959 “La II-a Internacia Konferenco de MEM en la kadro de la 44-a Universala Kongreso de Esperanto en Varsovio la 1-8. de aŭgusto 1959“, Paco dana-sveda eldono 6/67: 6.

Pedoman Isteri

1938 “Persatoean Kaoem Iboe Minangkabau”, Pedoman Isteri 7/11-12: 124.

Sennaciulo

1950 "Memornoto", Sennaciulo 21/7-8: 8.

Soerabaijasch Handelsblad

1887 “Nederlandsch-Indië", Soerabaijasch Handelsblad (13 October) 35/235: 2.

1888 "Brieven uit de hofstad; 's-Gravenhage, 24 November 1887", Soerabaijasch Handelsblad (5 January) 36/3: 1.

1930 "Radio-causerie", Soerabaijasch Handelsblad (31 December) 78/297: 6.

1931 "Lezing voor de radio", Soerabaijasch Handelsblad (21 April) 79/90: 6.

Sudazia Bulteno

1958 "Naskiĝtago", Sudazia Bulteno 1/1: 1.

The Australian Esperantist

1975 "News-digest - Diplomatic service", The Australian Esperantist (juniojulio) 139/219: 16.

The British Esperantist

1912 "Esperanto Progress Abroad; Dutch East Indies", The British Esperantist 8/92: 158.

Tutmonda Jarlibro Esperantista

1906 Tutmonda Jarlibro Esperantista, enhavanta the adresaron de Dro Zamenhof por 1906.

1907 Tutmonda Jarlibro Esperantista, enhavanta the adresaron de Dro Zamenhof por 1907. 


\section{Utrechts Nieuwsblad}

1952 “(No title) Op den 11den Januari [...]”, Utrechtsch Nieuwblad (12 January) 59/216: 12.

1952 “Ds. Kyftenbelt overleden", Utrechtsch Nieuwblad (12 January) 59/216: 2.

\section{Voĉo el Indonezio}

1954a "Eksposisi Esperanto", Voĉo el Indonesio [2]/[2]: 9-10.

1954b "La Tria Diplomdisdono en Djakarta", Voĉo el Indonesio [2]/[3]: 6.

1959 "Centra I.E.A. Djakarta", Voĉo el Indonezio [7]/?(August): [29].

1960a "Kongres I.E.A. ke-I ditunda", Voĉo el Indonezio 8/1: 10.

1960b "Pembentukan 'Islama Esperanto-Asocio'", Voĉo el Indonezio 8/1:11-12.

1960c "Nia unua konferenco", Voĉo el Indonezio 8/2: 1.

1960d "Apa kata pers di Indonesia tentang Konperensi Perama dari I.E.A.", Voĉo el Indonezio 8/2: 2-8.

1960e "Keputusan2 konperensi pertama dari I.E.A.", Voĉ el Indonezio 8/2:11-12.

$1960 f$ "Kegiatan organisasi-organisasi Esperanto selama berlangsungnja Konggres Esperanto Sedunia ke-44 di Warsawa; Islama EsperantoAsocio", Voĉo el Indonezio 8/2: 14.

1991 Voĉo el Indonezio 1?/11: 1.

\section{BASED ON AUTHORS}

Anonymous. [n.d.]. Lembaga Bahasa Esperanto Indonesia; Anggaran dasar. Semarang: Indonezia Esperanto-Asocio.

Anonymous. 1981. Tutmonda Esperantista Adresaro 1981. Marburg: Info-Servo r.a.

Arwani. [1954]. "Esperanto lingvo", Voĉo el Indonesio [2]/ [3]: 4-5.

Blackburn, Susan. 2000 "Political relations among women in a multi-racial city; Colonial Batavia in the twentieth century", in: Kees Grijns and Peter J.M. Nas (eds), Jakarta-Batavia; Socio-cultural essays, pp. 175-198. Leiden: KITLV Press.

Blackburn, Susan. 2004a. Women and the state in modern Indonesia. Cambridge: Cambridge University Press.

Blackburn, Susan. 2004b. "Women's suffrage and democracy in Indonesia", in: Louise Edwards and Mina Roces (eds), Women's suffrage in Asia; Gender, nationalism and democracy, pp. 79-105. London: RoutledgeCurzon.

Broto, D. 1958. "Amiko Esperanta, Kawanku", attachment to Kedaulatan Rakyat 20 December.

Chapman, Hilary. 2013. "Neeldonitaj paperoj de iama mondvojaĝanto", Brita Esperantisto 109/974: 37.

Cribb, R. and A. Kahin. 2004. Historical dictionary of Indonesia. Lanham: Scarecrow Press.

Datoe Toemenggoeng, Rkj. Ch. Sj. 1936a. "Bestrijding van den vrouwenhandel", in: M.A.E. van Lith-van Schreven and J. Hooykaas-van Leeuwen Boomkamp, Indisch vrouwen jaarboek, pp. 55-57. Yogyakarta: Kolff-Buning. 
Datoe Toemenggoeng, Rkj. Ch. Sj. 1951. “Letter to Julia Isbrücker, 20/12/1951”. [Archive of Internacia Esperanto-Ligo, correspondence between Cseh Privat, Julia Isbrücker, and Jan Isbrücker. Letter is signed with Chailan and "Toemenggoeng" is written on top of the letter for archiving purposes.] Datoe Toemenggoeng, Rkj. Ch. Sj. 1953. "Gerakan Esperanto di Indonesia", La Modera Voĉ de Indonezia UEA 1/2: 1-2. [Esperanto translation pp. 2-3.] Datoe Toemenggoeng, Rkj. Ch. Sj. 1958. 30 Tahun menentang polygami. Djakarta: Penerbit Chailan Sjamsoe.

Datoe Toemenggoeng, Rkj. Ch. Sj. [1959]. Dengan paspor Republik Indonesia. Djakarta: Penerbit Chailan Sjamsoe.

Djohar, Rimba. 1969. Pancasila dan agama Konfusius. Semarang: Indonezia Esperanto-Instituto.

Doi, Ĉieko. 1995. Esperanto-Movado en Azio. Jokohamo: Mevo-Libroj. Isbrücker, Julia. 1951. "Letter to Edmond Privat, 6/12/1951". [Archive of Internacia Esperanto-Ligo, correspondence between Cseh Privat, Julia Isbrücker, and Jan Isbrücker. - Letter is not signed.]

Kökény L. kaj Bleier V. 1933-34. Enciklopedio de Esperanto. Budapest: Literatura Mondo.

Liem, Tjong Hie. 1928. "El natura kaj sciencoj. La malaja lingvo", Esperanto 24/2: 29.

Liem, Tjong Hie. 1930. “Unuigho de GeEsperantistoj en Ned. Hindujo”, Hinda Esperantisto (March-April) [4]/8: [5].

Marin, Gaspard. 1951. “Vagado cirkaŭ la malnova mondo", La Migranto (JulyDecember) 1/1: 7-8.

Marin, Gaspard. 1974. G. Marin vizitas sian hejm on - la mondon; Kun prologo de Marinko, Givoje. Zagreb: Internacia Kultura Servo.

Marsoehar. 1958. "Bahasa Esperanto, Meladipri", attachment to Sin Min 20 December and 27 December.

Miyatake, Seidô. 1932a. "Java no Esperantistoj o tou", ${ }^{36}$ La Revuo Orienta 13/13: $455-457 .{ }^{37}$

Miyatake, Seidô. 1932b. Jawa no tabi. ${ }^{38}$ Nara: Miyatake Seidô.

Poeze, H.A. (ed.). 1983. Politiek-politioneele overzichten van Nederlandsch-Indië; Bronnenpublikatie. Deel II: 1929-1930. Dordrecht: Foris.

Poeze, H.A. (ed.). 1994. Politiek-politioneele overzichten van Nederlandsch-Indië; Bronnenpublikatie. Deel IV: 1935-1941. Dordrecht: Foris.

Scherer, Joseph Roman. 1931a. "Mond-vojaĝo por Esperanto - organizita de Internacia Centra Komitato de la Esperanto-Movado, Ĝenevo - Miaj unuaj tagoj en Javo (1)", Heroldo de Esperanto (5 June) 12/23 (623): 2.

36 The title was originally partly in Japanese, partly in Esperanto - Here the Japanese parts are transcribed and italic]. Translation: Visiting Esperantists in Java (with thanks to Gotoo Hitosi for the Japanese transcripts and translations, see also Miyatake 1932b).

37 The issue number 13 is a mistake. It should have been 12 . October got number 10 , while November got the number 12, instead of the correct 11, which does not seem to have appeared.

38 Japanese transcript, meaning: Journey to Java. 
Scherer, Joseph Roman. 1931b. “Mond-vojaĝo por Esperanto - organizita de Internacia Centra Komitato de la Esperanto-Movado, Ĝenevo - Miaj unuaj tagoj en Javo (2)", Heroldo de Esperanto (12 June) 12/24 (624): 2.

Scherer, Joseph Roman. 1931c. "Mond-vojaĝo por Esperanto - organizita de Internacia Centra Komitato de la Esperanto-Movado, Ĝenevo - Semarang kaj jarfino en Surabajo (1)", Heroldo de Esperanto (10 July) 12/ 28 (628): 2.

Scherer, Joseph Roman. 1931d. “Mond-vojago por Esperanto - organizita de Internacia Centra Komitato de la Esperanto-Movado, Ĝenevo - Semarang kaj jarfino en Surabajo (2)", Heroldo de Esperanto (17 July) 12/ 29 (629): 2.

Scherer, Joseph Roman. 1933. Cirrkaŭ la mondon kun la verda stelo. Köln: Heroldo de Esperanto.

Slinger, Nick H. 1931. "Nick H. Slinger - nova propagandist", Heroldo de Esperanto (9 October) 12/41: 1.

Steiner, Hugo. 1950. Tutmonda Adresaro de Esperantistoj. Korneŭburg: Niederösterreichischer Verlag.

Sunardo, Eriko. 1995. Interview 24 December 1995. [“Emil Vokal of Radio Aŭstria Internacia interviewed Sunardo", available after login from: http://www.ipernity.com/doc/69959/13814817.]

Wieringa, Saskia E. 2002. “3. The Garuda takes flight; From the colonial period to Independence", in: Saskia E. Wieringa, Sexual politics in Indonesia, pp. 52-96. Basingstoke: Palgrave Macmillan. [Institute of Social Studies series.] Wirdjosaksono, K. 1925. "Kiamaniere la javano edziĝas?", Esperanto 23/3: 3-4. 